\begin{tabular}{|l|l|l||}
\hline \multicolumn{2}{|c|}{ PublisherInfo } \\
\hline \hline PublisherName & $:$ & BioMed Central \\
\hline \hline PublisherLocation & $:$ & London \\
\hline \hline PublisherImprintName & $:$ & BioMed Central \\
\hline \hline
\end{tabular}

\title{
A clinical link between apoptosis and autoimmunity
}

\begin{tabular}{|l|l|l||}
\hline \multicolumn{2}{|c||}{ ArticleInfo } \\
\hline \hline ArticleID & $:$ & 5 \\
\hline \hline ArticleDOI & $:$ & $10.1186 /$ ar-2000-66817 \\
\hline \hline ArticleCitationID & $:$ & 66817 \\
\hline \hline ArticleSequenceNumber & $:$ & 1 \\
\hline \hline ArticleCategory & $:$ & Paper Report \\
\hline \hline ArticleFirstPage & $:$ & 1 \\
\hline \hline ArticleLastPage & $:$ & 3 \\
\hline \hline & $:$ & RegistrationDate : 2000-6-8 \\
ArticleHistory & $:$ & OnlineDate \\
\hline \hline ArticleCopyright & $:$ & Current Science Ltd2000-6-8 \\
\hline \hline ArticleGrants & $:$ & \\
\hline \hline ArticleContext & $:$ & 130752211 \\
\hline \hline
\end{tabular}




\section{Keywords}

Apoptosis, autoantibodies, autoantigen, MCTD, Raynaud's phenomenon, SLE, U1 snRNP

\section{Context}

he U1-70 kDa protein is one of the major autoantigenic components in the U1 small nuclear RNP complex (U1 snRNP). Autoantibodies recognizing this protein are primarily present in systemic lupus erythematosus (SLE) and SLE overlap diseases, such as mixed connective tissue disease (MCTD). Previous studies have suggested that a correlation exists between the clinical features of the patient and the immunodominant epitope that is recognized. It has also been suggested that apoptotic modifications of autoantigens may trigger the develop- ment of autoimmunity. The U1-70 kDa protein can be cleaved during apoptosis in different ways. Apoptosis induced by UV irradiation produces a $40 \mathrm{kDa}$ cleavage product, while metal-catalyzed oxidative cleavage produces apoptotic fragments of 33 to $38 \mathrm{kDa}$. The latter products could be formed during ischemia-reperfusion in Raynaud's phenomenon (RP), while the former product could arise in photosensitive lupus patients. To test whether preferential recognition of the $40 \mathrm{kDa}$ apoptotic product would occur in patients with sun-sensitive cutaneous lupus, but not in patients with RP and vice versa (whether the 33-38 kDa products would be preferentially recognized by autoantibodies in patients with RP, but not in UV-sensitive patients).

\section{Significant findings}

Patients with lupus skin disease preferentially recognized the $40 \mathrm{kDa}$ apoptotic fragment as compared to patients with no skin disease. This difference was statistically significant, and not apparent between the RP group and the non-RP group. Conversely, the oxidatively produced 33-38 kDa fragments were preferentially recognized by the RP group as compared to the group without RP. This correlation was not found in the skin disease group as compared to the no skin disease group.

\section{Comments}

It has been hypothesized already for some years that autoantibody production might be linked to the immune presentation of modified forms of autoantigens. In particular, several reports have shown that 
such modified antigens are produced during apoptosis and could be exposed to the immune system when clearance of dying cells is inadequate. This paper clearly supports such a mechanism and provides the first in vivo evidence that autoimmune responses to different modified forms of a self antigen (the cleavage products of the U1-70 kDa component of the ribonucleoprotein [RNP] autoantigen) correlate with distinct clinical phenotypes. This constitutes a very interesting result that should initiate similar studies using other autoantigens.

\section{Methods}

Autoimmune responses were measured by immunoblotting, and normalized using the intact U1-70 $\mathrm{kDa}$ antigen as substrate. The resulting apoptotic fragment recognition indices were correlated with patients grouped by photosensitivity or RP status.

\section{References}

1. Greidinger EL, Casciola-Rosen L, Morris SM, Hoffman RW, Rosen A: Autoantibody recognition of distinctly modified forms of the U1-70-kd antigen is associated with different clinical disease manifestations. Arthritis Rheum. 2000, 43: 881-888.

This PDF file was created after publication. 